\title{
Analysis on Strategy of Enhancing Logistics Competitiveness of Xi 'an International Land Port
}

\author{
Weixia Yang \\ School of business, Xi'an International University \\ Xi'an, China \\ wxyang741117@163.com
}

Keywords: land port logistics; international competitiveness; strategy analysis; logistics industry

\begin{abstract}
With the arising of service economy, logistics industry plays a more important role in national economy and the competitiveness of logistics industry has become one important factor that determines the national comprehensive competitiveness. $\mathrm{Xi}$ 'an government attaches great importance to the development of logistics industry, it implement scheme of " the port city", and has established the xi 'an international land port, aiming to provide a new direction for the international land port construction, and strategic analysis and strategy analysis to xi 'an international land port competitiveness of ascension. xi 'an international land port logistics are in an inferior position compared with foreign counterparts. In order to turn the inferior situation, it is urgent to enhance the competitiveness of $\mathrm{Xi}$ 'an international land port. In this paper, the author stared with relevant definitions, and analysis competitiveness decisive factors. It Focus on analyzing the present situation and problems of xi 'an land port international logistics, and Find out constructive Suggestions how to promote the competitiveness of the xi 'an international land port logistics, in order to help the development of xi 'an land port international logistics.
\end{abstract}

\section{Introduction}

Since the concept of logistics was introduced into China, the logistics has become one of the rapid development industry in China. the xi 'an city authorities also pay attention to the logistics industry. It construct the powerful international logistics center of xi 'an land port, and realize the logistics development planning that develop port logistics what regards logistics as the basic characteristics, and develop inter-city distribution logistics based on e-commerce. In the face of complex and changeful environment of the world political and economic situation, xi 'an international land port logistics industry will go from here under developing rapidly and the competitive uncertain market factors. This article will analysis status of xi 'an international land port logistics industry, explore its advantages and disadvantages, and suit the remedy to the case. Finally, the author analysi the existing problems and deficiency, and then puts forward the strategy to increase the competitiveness of $x i$ 'an international land port. As a modern logistics industry and new trend of developme ${ }^{1} n t$,international inland port is able to int egrate logistics resources to enhance logistics efficiency,and promote the development of inland exp ortoriented economy.Therefore, it is very important to our country regional economy development.

\section{Connotation and Characteristics of International Land Port Logistics Competitiveness}

\section{Connotation of international land port logistics competitiveness.}

"International land port" refers to the international commercial port in the inland areas, that is develop by means of modern information technology, by regarding the road transport as the main way that adopt the method of multimodal transport by comprehensive highway, railway, aviation, shipping and other modes of transportation advantage, in accordance with the relevant international transport regulations. It is the extension and expansion of a coastal ports in the inland economy

\footnotetext{
${ }^{1}$ Project of special scientific research plan in education department of Shaanxi province (14JK2100)
} 
functions center city, is the modern producer services in regional economic development zones. It has the following functions: international port service function, goods distribution, transfer function, third-party logistics services, processing value-added function, circulation, commodity exhibition function, logistics information service function

\section{Characteristic of international land port logistics competitiveness.}

1) Dependent on the interior economy

In the regional economic system, development level of industrial, the level of support, complete degree of supply, financial services, information and market share of hinterland sourcing all will directly determine the competitiveness of international land port logistics.

2) Wide range of radioactive

International land port logistics is a relatively active economic activities, and its need to assemble all the resources to complete the circulation of goods or services, deployment and production. So the region participating in the activities and its surrounding areas will be affected by its port radiation. Similarly, the radioactive of international land port logistics competitiveness not only can be the scope of region, is also the number of the industry.

3) Limitations of competition way

In modern society, because of the facilitation of information and the globalization of economy, service mode and efficiency of International land port logistics at present will not be too big disparity. Coupled with port operations giant holding the service quality in a globalized network model, and, in such a no too big difference service, the competition space of international land port logistics is shown slightly narrow.

\section{The influence factors of international land port logistics competitiveness.}

International land port logistics activities have penetrated into almost every economic industry sectors, so there are many factors that can affect international land port logistics competitiveness, the main influencing factors as follows:

1) The development level of economic

Because logistics is the third industry, level of national economy as a whole has had a huge impact to it. Experience has proved that that the development of the third industry is doing fine in the economy seminary areae. so it can be seen that the economy is the basis to provide abundant material for the development of this regional logistics.

2) International land port geographic position

The superiority of geography, not only can reduce the cost of logistics, and can improve the efficiency and level of logistics service, so as to these are making these areas more and more attractive to the logistics resources, and to expand the radiation of area logistics. Eventually, they may improve the international land port logistics competitiveness.

3) Regional industry and its structure

The mode by which agricultural products terminal sales infor In the course of development of International land port logistics, it involved in industrial, agricultural, commercial and construction, and other industries. Economic theory suggests that the smooth development of land port logistics is a good way to promote the development of its relevant industries, that is association effect land port logistics. Regional industrial structure and the trend of change will have important influence on the logistics service lever of land port logistics facilities and the logistics scale. Eventually, thus affect the comprehensive competitiveness of land port logistics. 


\section{The development status quo analysis of Xi'an international land port logistics competitiveness}

\section{$\mathrm{Xi}$ 'an international land port profile.}

In the $\mathrm{Xi}$ 'an city, the international harbor area was formally established in 2008. And it is a provincial development areas capitalizes on Business logistics, aimed at the development of xi 'an geographic advantages and radiation impetus function in the center of the new asia-europe continental bridge area, and then it may provide efficient complete modern service facilities, highquality platform closely linked world window for the economic development of northwest region. Its ultimate goal is to become the largest land port and the largest international trade and logistics distribution center. So according to the service scope of xi 'an international land port, and the nature of the land port itself, xi 'an international land port will become an international hub transformation of land port.

\section{Problems of xi 'an international land port logisticst.}

Although $\mathrm{Xi}$ 'an land port preliminary has functions such as for port, bonded logistics and transportation, but not yet forming, in the land port operation efficiency and business capability and related hardware, software, facilities it also has many deficiencies. At present, xi 'an land port development still exist in the following specific questions:

1)Multimodal transport network is imperfect

At present, multimodal transport network of xi 'an international inland port is not sound." xi 'an highway port isn't up and running yet, the xi 'an railway container terminal "rail sea transport" has not give full play to the function. These have greatly reduced the attractive of hinterland inland port to cargo distribution and transit.

2) Operations efficiency of Xi 'an international inland port has yet to beupgrade

Although the function of the xi 'an international inland port has basically achieved, it has yet to beupgrade in construction of the logistics channel, for example: the speed of customs, channel construction, the information feedback and so on.

3) Land port transportation did not achieve economies of scale

Take, for example railway transportation resources, in shaanxi, where are ready to offer you the container business that includs xi 'an container center station, xi 'an east, xi 'an west, xianyang, baoji east, weinan, Seoul, hanzhong, etc. But container center station standing on the geographical distribution of dense, it is very adverse to the rectification of goods. So now we need urgently to supply concentrated basins of every cargo terminal to central station, to expand the scale of the center station.

4) Industrial agglomeration effect of Xi 'an comprehensive free trade zone has not yet appeared

For Xi 'an comprehensive free trade zone, it is lag in terms of speed of construction and the investment promotion and capital introduction. in March 2014, xi 'an high-tech comprehensive free trade zone will start the operation, so it can't maintain its first-mover advantage, so that they cannot make the xi 'an high-tech comprehensive free trade zone forming scale economy, which makes the core of its industry drives effect is not play, and xi 'an land port status can not be revealed.

\section{The strategy of improving xi 'an international port competitiveness}

\section{To give strong policy support.}

We may the management model of zone manage the street running. The government give money to support the construction of logistics infrastructure, give policy support for the coming logistics enterprises, and give tax breaks to the logistics business. We make full use of the means of market regulation to realize the development of inland port in the right pattern justied international business.

\section{To manage and guide in planning layout.}

Government must complete the layout of construction of the inland port, to realize mutual cooperation, complement each other, common development, to avoid the construction of function overlapping. We should analyze the industry, product sales, the market demand within the scope of 
inland port radiation and construct the according logistics facilities to avoid of overlapping logistics center or inland port industry.

\section{To strengthen the construction of supporting in transportation system.}

Firstly, we should speed up the construction of railway, especially the construction of highspeed railway. Secondly, we should accelerate the construction of highways and flyovers, because we may effective guidance and service of inland port logistics activity by highway and interchange. Finally, we should speed up the construction of transportation information system, and integrate transportation information system, unified organization management and traffic information.

\section{To consciously guard against risks in operation.}

We should be based on local actual, not blindly go in for grandiose projects. We also should construct inland port with a unified planning and step-by-step implementation, and gradually expand and increase the construction scale and facilities of ownership of the inland port according to the continuous development of trade and logistics business, to prevent the facilities available. At the same time, we should to balance development of internal logistics, trade and foreign trade, avoiding excessive dependence on foreign trade..

\section{To set for port logistics information platform.}

We should Will increase the construction of information platform, and highly integrate shipping, railway, highway transportation channel. By GPS and other technology, we may achieve logistics information in time, enhance the service level and overall competitiveness of land port.The efficient information platform will promote each department together with the management, the establishment of collaborative management mechanism, promote the sharing of information.

\section{To Introduct and train logistics talents.}

Qualified personnel is an important guarantee to realize the sustainable development of port. First of all, we need to formulate relevant welfare policy to attract high-quality talents to work in xi 'an international land port. Second, we should encourage on-the-job personnel to participate in training or study to improve their ability to work. Third, we should accelerate the occupational qualification certification system, to make xi 'an international land port staff work with the certificate. Fourth, we should establish strict assessment mechanism, and regularly performance evaluation, supervise and urge to employee.

\section{Summary}

The construction of xi 'an international land port created good conditions and development platform for the development of logistics industry and upgrade. It can promote development of regional export-oriented economy, and opened up the channel of international trade, maximize the advantages of the region. At present, the development of $\mathrm{Xi}$ 'an international land port logistics still exist many problems, But we believe that it will become the national modern logistics industry demonstration garden and modern service industries demonstration zone, out tomorrow, will also be a modern, ecological, integrated "modern service industry city"

\section{References}

[1] Roso V,Lumsden K.The dry port concept-Moving seaport activities inland?[Z].Transportand Communications Bulletin for Asia and thePacific,2009,(78):87 101.

[2] Castillo-Manzano J I.Low-cost portcompetitiveness index:Implementation in theSpanish port system[J].Marine Policy,2009,33:591 598.

[3] Aronietis R.Some effects of hinterlandinfrastructure pricing on port competitiveness:Case of Antwerp[J].Transport and RegionalEconomics,2010,7:26 27,29,31.

[4] Tongzon J.Port privatization,efficiency andcompeti-tiveness:Some empirical evidence fromcontainer ports(terminals)[J].TransportationResearch Part,2005,A39:405 424

[5] Vinodh S,et al.Application of fuzzy analyticnetwork process for supplier selection in 
amanufacturing organization[J].Expert Systemswith Applications,2011,38:272 280.

[6] Chang D Y.Applications of the extent analysismethod on fuzzy AHP[J].European Journal ofOperational Research,1996,95:649 655. 